\title{
DATING GRIMES GRAVES
}

\author{
JANET AMBERS \\ Department of Scientific Research, The British Museum, London WC1B 3DG, United Kingdom
}

\begin{abstract}
More radiocarbon analyses have been produced for the Neolithic flint mines of Grimes Graves than for any other site with which the British Museum's Radiocarbon Laboratory has been involved. Despite this heavy concentration of effort, a recent review of these figures concluded that poor sample selection, combined with a lack of sufficient quality assurance procedures, severely limit the use that can be made of this database. To overcome these difficulties, a redating program has been undertaken using a carefully selected subset of the original material. In this paper I discuss the flaws in the original data set, due to both technical and sampling problems; set out ways to avoid similar problems in the future, with particular reference to quality assurance; and discuss the new results and their archaeological implications.
\end{abstract}

\section{INTRODUCTION}

In the five decades since it was first postulated, ${ }^{14} \mathrm{C}$ dating has become the single most used dating technique in archaeology, and has, without question, revolutionized our understanding of the past. Many thousands of ${ }^{14} \mathrm{C}$ analyses now exist, and form one of the most frequently exploited databases in archaeology. Unfortunately, it also tends to be one of the most misused databases, largely because of a failure to critically examine the quality of individual measurements.

Archaeology differs in many ways from other disciplines in which ${ }^{14} \mathrm{C}$ plays a role, and is arguably unique as a user group of ${ }^{14} \mathrm{C}$ dates. It demands the highest (sometimes impossibly high) precision, with one of the most limited sample bases, and even more limited funding. Samples are often effectively unique; even if further material does exist it may be unobtainable because of lack of money, or because further excavation on a particular site is not possible. Archaeology tends therefore to rely far more on the existing ${ }^{14} \mathrm{C}$ archive than any other field, regularly using, often without question, results several decades old. Few archaeologists have a basis in science; there is a tendency in the community to either accept or reject scientifically generated analyses wholesale, rather than to critically review and sift the evidence. This situation is improving rapidly, with encouragement from the ${ }^{14} \mathrm{C}$ laboratories, but problems still remain-for example, while it occurs to most archaeologists to consider the possibility of interlaboratory variability, they are far less aware of the possibility of intralaboratory variation.

As has to be expected with a technique in constant use for $>40 \mathrm{yr}$, many advances have been made both in understanding the physical processes underlying ${ }^{14} \mathrm{C}$ theory and in methodology. Samples are now cleaned, treated and measured in radically different ways than those materials put into the first solid-state or gas counters. Materials thought suitable for dating $20 \mathrm{yr}$ ago have proved to be unreliable, for physical or chemical reasons, and the need for increasingly complex methods of quality assurance has become more apparent. Yet many archaeologists continue to use any and all ${ }^{14} \mathrm{C}$ analyses as if they were of equal value, and to assume that all published results provide equally valid data, something that is demonstrably untrue. It is becoming increasingly obvious that many of the results in the existing ${ }^{14} \mathrm{C}$ archive are flawed, and should be used only with caution, if at all.

The recent publication of a fascicule summarizing the evidence from the deeper mines at Grimes Graves, Norfolk (Longworth and Varndell 1996) prompted a reexamination of the ${ }^{14} \mathrm{C}$ figures from the site. A large database of ${ }^{14} \mathrm{C}$ measurements exists for Grimes Graves: a total of 147 British Museum analyses, reflecting the extent of the Museum's involvement with this important site. Of these, 76 relate to Neolithic activity in the deeper mines. These measurements were made over a period of many years, from 1961 to 1986 , and thus bracket much of the period that ${ }^{14} \mathrm{C}$ has been used 
in archaeology. Moreover, they all come from a single laboratory, removing the complications of interlaboratory variation. It therefore seems useful to review these data critically and examine how their limitations reflect those of the total ${ }^{14} \mathrm{C}$ archive. For the purpose of this paper, discussion will be confined to Neolithic material from the deeper mines.

\section{SITE DESCRIPTION}

Grimes Graves is the name historically given to a prehistoric flint-mining complex in Norfolk, England $\left(52^{\circ} 30^{\prime} \mathrm{N}, 0^{\circ} 40^{\prime} \mathrm{E}\right.$, Natl Grid Ref TL 816898). The site is massive, with evidence of Neolithic flint extraction spread over some 37 ha. This includes both large-scale galleried shafts and smaller opencast workings. The basic geology of the area is of a chalk bedrock, in which flint occurs in three separate bands. All of these bands were utilized in antiquity, but the best quality flint came from the "floorstone", the lowest band, which was sufficiently deep to escape the destructive effects of periglacial activity, and thus exists in large tabular lumps. To reach this layer, the Neolithic miners dug shafts up to $15 \mathrm{~m}$ deep. When the floorstone layer was reached it was further exploited by digging galleries outwards. Typically the shafts of these mines are 4-8 $\mathrm{m}$ in diameter at the surface, and 5 to $15 \mathrm{~m}$ in depth, with low horizontal galleries radiating from the base of each shaft, often interconnecting with the galleries of adjacent shafts. More than 350 infilled large-scale shafts and galleries have been located, although only $c a .20$ of these have been explored to any extent. A rough calculation indicates that one of these galleried mines could yield as much as 40 metric tons of floorstone, giving a total figure in excess of 14,000 metric tons for the entire site. The evidence of opencast mining at the site is less spectacular, but clearly demonstrated by a large number of smaller pits, 2-4 $\mathrm{m}$ in diameter and 2-3 $\mathrm{m}$ deep.

As might be expected, given the instant recognizability of the ancient workings, the site has excited antiquarian interest over a long period, with actual excavation taking place sporadically for much of the last $150 \mathrm{yr}$. The first recorded investigations were those conducted by Canon Greenwell in the 1860 s, in the course of which he opened the shaft now known as Greenwell's Pit. Other excavations include those of Peake (1919) between 1914 and 1917 and Armstrong (1934) between 1921 and 1939. The first major postwar work was undertaken by Mercer (1981) in 1971 and 1972, and more recently the British Museum conducted several seasons' work between 1972 and 1976.

Over the years, these excavations have yielded a wealth of material and evidence. Of particular importance to the dating of the site is the survival of very large numbers of red deer antlers, evidently used as mining tools. Over 400 such objects were recovered during the British Museum excavations alone.

\section{METHODS}

\section{The Existing Database}

A full list of existing ${ }^{14} \mathrm{C}$ analyses produced for the Neolithic workings in the deeper mines at Grimes Graves is given in Table 1; for more details of individual samples see Appendix D of Longworth and Varndell (1996). Results are quoted in the form recommended by Stuiver and Polach (1977), corrected for isotopic variation where possible (the British Museum did not acquire a mass spectrometer until 1969).

Only a brief summary of the methods is given here; for full details the relevant Radiocarbon date list should be consulted (see listing in Appendix below). Methods were, in general, consistent within each date list, and the details given here are therefore divided by publication date. 
TABLE 1. Radiocarbon Results for the Deep Mines at Grimes Graves

\begin{tabular}{|c|c|c|c|c|c|}
\hline $\begin{array}{l}\text { BM- } \\
\text { no. }\end{array}$ & $\begin{array}{l}\text { BM date } \\
\text { list }\end{array}$ & Material & Pit number and context & $\begin{array}{l}\delta^{13} \mathrm{C} \\
(\% o)\end{array}$ & $\begin{array}{l}{ }^{14} \mathrm{C} \text { age } \\
(\mathrm{yr} \mathrm{BP})\end{array}$ \\
\hline \multicolumn{6}{|c|}{ 1. Armstrong and Greenwell Excavations } \\
\hline 87 & III & Charcoal & 15 , shaft at $14 \mathrm{ft}$. & -- & $4270 \pm 150$ \\
\hline 88 & III & Antler & 15 , shaft at $11 \mathrm{ft}$. & -- & $4050 \pm 150$ \\
\hline 93 & IV & Antler & 10 & -- & $3870 \pm 150$ \\
\hline 97 & IV & Antler & 12 & -- & $4290 \pm 150$ \\
\hline 99 & IV & Antler & 14 & -- & $3980 \pm 150$ \\
\hline 103 & IV & Antler & 11 & -- & $3700 \pm 150$ \\
\hline 109 & IV & Antler & 8 & -- & $3290 \pm 150$ \\
\hline 276 & VI & Antler & 12 & -- & $3550 \pm 150$ \\
\hline 291 & VI & Antler & Greenwell, gallery & -- & $3810 \pm 130$ \\
\hline 377 & VI & Antler & & -- & $4250 \pm 130$ \\
\hline \multicolumn{6}{|c|}{ 2. 1971 Shaft } \\
\hline 775 & VIII & Charcoal & 1971 shaft, gallery 3 & -- & $3815 \pm 60$ \\
\hline 776 & VIII & Charcoal & 1971 shaft, hearth in centre of pit floor & -- & $3789 \pm 60$ \\
\hline 777 & VIII & Charcoal & 1971 shaft, entrance to gallery 1 & .- & $3764 \pm 60$ \\
\hline 778 & VIII & Charcoal & 1971 shaft, top of shaft fill & -- & $3781 \pm 67$ \\
\hline 943 & VIII & Antler & $\begin{array}{l}1971 \text { shaft, beside hearth in corner of pit } \\
\text { floor }\end{array}$ & -- & $4104 \pm 55$ \\
\hline 944 & VIII & Antler & 1971 shaft, gallery 1 & -- & $4153 \pm 64$ \\
\hline 945 & VIII & Antler & 1971 shaft, gallery 3 & -- & $4034 \pm 88$ \\
\hline 1097 & & Charcoal & 1972 , trench 10 , layer 5 & -- & $3038 \pm 44$ \\
\hline \multicolumn{6}{|l|}{ 3. Pit 15} \\
\hline 971 & $\mathbf{X}$ & Charcoal & 151 , gallery & -25.8 & $3868 \pm 66$ \\
\hline 972 & $\mathbf{X}$ & Charcoal & $15 \mathrm{D} 3$, gallery & -27.4 & $3071 \pm 209$ \\
\hline 973 & $\mathbf{X}$ & Antler & $15 \mathrm{~A} 1$, gallery & -24.2 & $3827 \pm 45$ \\
\hline 974 & $\mathbf{X}$ & Antler & $15 C 2$, gallery & -24.1 & $3887 \pm 47$ \\
\hline 975 & $\mathbf{X}$ & Antler & $15 \mathrm{~B} 1$, gallery & -24.1 & $3940 \pm 41$ \\
\hline 976 & $\mathbf{X}$ & Antler & $15 \mathrm{G} 1$, gallery & -23.0 & $3849 \pm 44$ \\
\hline 977 & $\mathbf{X}$ & Antler & $15 \mathrm{~F} 2$, gallery & -24.5 & $4015 \pm 61$ \\
\hline 978 & $\mathbf{X}$ & Antler & $15 \mathrm{D} 2$, gallery & -25.0 & $3865 \pm 44$ \\
\hline 979 & $\mathbf{X}$ & Antler & $15 \mathrm{~J} 1$, gallery & -25.0 & $3820 \pm 46$ \\
\hline 980 & $\mathbf{X}$ & Antler & $15 \mathrm{D} 1$, gallery & -24.8 & $3736 \pm 58$ \\
\hline 986 & $\mathbf{X}$ & Charcoal & $15 \mathrm{~J} 1$, gallery & -25.9 & $3845 \pm 44$ \\
\hline 996 & $\mathbf{X}$ & Antler & $15 \mathrm{~B} 3$, gallery & -23.6 & $3890 \pm 42$ \\
\hline 997 & $\mathbf{X}$ & Antler & $15 \mathrm{C} 1$, gallery & -24.9 & $3960 \pm 56$ \\
\hline 998 & $\mathbf{X}$ & Antler & $15 \mathrm{E} 2$, gallery & -23.0 & $3992 \pm 45$ \\
\hline $1000 \mathrm{a}$ & $\mathbf{X}$ & Antler & $15 \mathrm{G}$, gallery & -23.2 & $4051 \pm 109$ \\
\hline $1000 \mathrm{~b}$ & $\mathbf{X}$ & Antler & $15 G$, gallery & -23.2 & $4022 \pm 87$ \\
\hline 1001 & $\mathbf{X}$ & Antler & 15J?, gallery & -23.3 & $3868 \pm 56$ \\
\hline 1002 & $\mathbf{X}$ & Antler & $15 \mathrm{E} 1$, gallery & -21.2 & $3882 \pm 45$ \\
\hline 1003 & $\mathbf{X}$ & Antler & $15 \mathrm{~B} 2$, gallery & -22.5 & $3949 \pm 42$ \\
\hline 1011 & $\mathbf{X}$ & Antler & $15 \mathrm{D} 2$, gallery & -22.5 & $3952 \pm 44$ \\
\hline 1051 & $\mathbf{X}$ & Antler & $15 \mathrm{~B} 1$, gallery & -23.2 & $3887 \pm 56$ \\
\hline $1052 \mathrm{~A}$ & $\mathbf{X}$ & Antler & $15 \mathrm{~B} 2$, gallery & -22.9 & $4114 \pm 45$ \\
\hline $1052 \mathrm{~B}$ & $\mathbf{X}$ & Antler & $15 \mathrm{~B} 2$, gallery & -22.9 & $3954 \pm 43$ \\
\hline 1053 & $\mathbf{X}$ & Antler & $15 \mathrm{~A} / \mathrm{B}$, gallery & -23.3 & $3834 \pm 50$ \\
\hline 1054 & $\mathbf{X}$ & Antler & $15 C 2$, gallery & -22.2 & $3904 \pm 36$ \\
\hline
\end{tabular}


TABLE 1. Radiocarbon Results for the Deep Mines at Grimes Graves (Continued)

\begin{tabular}{|c|c|c|c|c|c|}
\hline $\begin{array}{l}\text { BM- } \\
\text { no. }\end{array}$ & $\begin{array}{l}\text { BM date } \\
\text { list }\end{array}$ & Material & Pit number and context & $\begin{array}{l}\delta^{13} \mathrm{C} \\
(\% 0)\end{array}$ & $\begin{array}{l}{ }^{14} \mathrm{C} \text { age } \\
\text { (yr BP) }\end{array}$ \\
\hline $\begin{array}{l}1056 \mathrm{~A} \\
1056 \mathrm{~B} \\
1057 \\
1058 \\
1059 \\
1260 \\
1262\end{array}$ & $\begin{array}{l}\mathbf{X} \\
\mathbf{X} \\
\mathbf{X} \\
\mathbf{X} \\
\mathbf{X} \\
\mathbf{X} \\
\mathbf{X}\end{array}$ & $\begin{array}{l}\text { Antler } \\
\text { Antler } \\
\text { Antler } \\
\text { Antler } \\
\text { Antler } \\
\text { Antler } \\
\text { Charcoal }\end{array}$ & $\begin{array}{l}\text { 15D1, gallery } \\
\text { 15D1, gallery } \\
\text { 15D1/J1, gallery } \\
\text { 15E1, gallery } \\
15 \mathrm{~F} 2 \text {, gallery } \\
\text { 15D4, gallery } \\
15 \mathrm{D} 4 \text {, gallery }\end{array}$ & $\begin{array}{l}-23.8 \\
-23.8 \\
-23.0 \\
-22.9 \\
-22.6 \\
-22.5 \\
-24.7\end{array}$ & $\begin{array}{l}3838 \pm 42 \\
3740 \pm 48 \\
3924 \pm 47 \\
3876 \pm 48 \\
3977 \pm 47 \\
4037 \pm 62 \\
3900 \pm 54\end{array}$ \\
\hline $\begin{array}{l}\text { 4. Pit } 11 \\
981 \\
982 \\
983 \\
984 \\
985 \\
987\end{array}$ & $\begin{array}{l}\mathbf{X} \\
\mathbf{X} \\
\mathbf{X} \\
\mathbf{X} \\
\mathbf{X} \\
\mathbf{X}\end{array}$ & $\begin{array}{l}\text { Antler } \\
\text { Antler } \\
\text { Antler } \\
\text { Antler } \\
\text { Antler } \\
\text { Charcoal }\end{array}$ & $\begin{array}{l}11 \mathrm{~A} \text {, gallery } \\
11 \mathrm{~B} / \mathrm{E} \text {, gallery } \\
11 \mathrm{D} \text {, gallery } \\
11 \mathrm{E} \text {, gallery } \\
11 \mathrm{~F} \\
11 \mathrm{~B}-\mathrm{E} \text {, gallery }\end{array}$ & $\begin{array}{l}-22.8 \\
-21.0 \\
-21.7 \\
-23.1 \\
-23.0 \\
-26.0\end{array}$ & $\begin{array}{l}3874 \pm 47 \\
4090 \pm 58 \\
3761 \pm 48 \\
3902 \pm 58 \\
4010 \pm 59 \\
3671 \pm 75\end{array}$ \\
\hline $\begin{array}{l}5 . \text { Greenh } \\
1027 \\
1028 \\
1029 \\
1044 \\
1045 \\
1046 \\
1047 \\
1048 \\
1049 \\
1050 \\
1068 \\
1261 \\
2377 \\
2380\end{array}$ & $\begin{array}{l}\text { vell's Pit } \\
\text { X } \\
\text { X } \\
\text { X } \\
\text { X } \\
\text { X } \\
\text { X } \\
\text { X } \\
\text { X } \\
\text { X } \\
\text { X } \\
\text { X } \\
\text { XX } \\
\text { XX } \\
\text { XX }\end{array}$ & $\begin{array}{l}\text { Antler } \\
\text { Antler } \\
\text { Antler } \\
\text { Antler } \\
\text { Antler } \\
\text { Antler } \\
\text { Antler } \\
\text { Antler } \\
\text { Antler } \\
\text { Antler } \\
\text { Antler } \\
\text { Antler } \\
\text { Charcoal } \\
\text { Antler }\end{array}$ & $\begin{array}{l}\text { Greenwell III' }{ }^{2} \text {, gallery } \\
\text { Greenwell IV, gallery } \\
\text { Greenwell C, gallery } \\
\text { Greenwell IV, gallery } \\
\text { Greenwell C, gallery } \\
\text { Greenwell C, gallery } \\
\text { Greenwell C, gallery } \\
\text { Greenwell IVc, gallery } \\
\text { Greenwell IIb, gallery } \\
\text { Greenwell A, gallery } \\
\text { Greenwell A, gallery } \\
\text { Greenwell III3a, gallery } \\
\text { Greenwell } \\
\text { Greenwell }\end{array}$ & $\begin{array}{l}-23.0 \\
-19.5 \\
-22.4 \\
-22.3 \\
-23.3 \\
-20.3 \\
-22.6 \\
-21.6 \\
-22.1 \\
-21.7 \\
-22.1 \\
-21.4 \\
-23.9 \\
-23.0\end{array}$ & $\begin{array}{l}3855 \pm 36 \\
3922 \pm 38 \\
3859 \pm 53 \\
3922 \pm 86 \\
3949 \pm 41 \\
3797 \pm 52 \\
3974 \pm 45 \\
3880 \pm 38 \\
3884 \pm 43 \\
3893 \pm 44 \\
3784 \pm 50 \\
3853 \pm 71 \\
4060 \pm 90 \\
3810 \pm 60\end{array}$ \\
\hline $\begin{array}{l}\text { 6. Pit 2 } \\
1020 \\
1069\end{array}$ & $\begin{array}{l}\mathrm{XX} \\
\mathrm{XX}\end{array}$ & $\begin{array}{l}\text { Antler } \\
\text { Antler }\end{array}$ & $\begin{array}{l}\text { Pit } 2 \text { A-B, gallery } \\
2 \text { A-B, gallery }\end{array}$ & $\begin{array}{l}-23.0 \\
-22.0\end{array}$ & $\begin{array}{l}3844 \pm 221 \\
3896 \pm 141\end{array}$ \\
\hline $\begin{array}{l}\text { 7. Pit } 3 A \\
1060 \\
779 \\
780 \\
812\end{array}$ & $\begin{array}{l}\text { VIII } \\
\text { VIII } \\
\mathbf{X X}\end{array}$ & $\begin{array}{l}\text { Antler } \\
\text { Charcoal } \\
\text { Charcoal } \\
\text { Antler }\end{array}$ & 3A Layer 10 & $\begin{array}{l}-23.5 \\
-26.6 \\
\end{array}$ & $\begin{array}{c}3863 \pm 86 \\
313 \pm 200 \\
2465 \pm 230 \\
3380 \pm 55\end{array}$ \\
\hline
\end{tabular}

The samples listed in date lists III and IV, together with BM-276, were measured by gas proportional counting of acetylene. Errors are based on counting statistics but with additional uncertainties of $\pm 80 \mathrm{yr}$ for possible isotopic variation and $\pm 100 \mathrm{yr}$ for natural atmospheric ${ }^{14} \mathrm{C}$ variation (de Vries effects) added in quadrature, in accordance with laboratory practice at the time.

All the remaining measurements were made by liquid scintillation counting of benzene in a succession of different counters. In these cases uncertainties are based on counting statistics alone. 
The modern standard used throughout was oxalic acid (HOxI or HOxII). Pretreatments used were similar throughout: for charcoal samples, hot acid and sometimes alkali washes, and for bone and antler, demineralization with dilute acid.

Table 1 includes three sets of double measurements (BM-1000a and -1000b; BM-1052a and -1052b; $B M-1056 a$ and $-1056 b$ ). Unfortunately, these suffixes were not used consistently. Of the three pairs, only BM-1000a and $-1000 \mathrm{~b}$ represent true replicates, being prepared from two separate subsamples of the same raw materials. The other two were produced by recounting of the same sample benzene at different times, and are therefore not independent.

\section{Discussion}

Reviewing these figures, it becomes obvious that, in the light of present knowledge, question marks must be attached to many of the results presented here. Certainly some of the materials included would not now be accepted by this laboratory as suitable for dating. This must include the unidentified charcoals as, without proper botanical examination, there is no guarantee that the species included were not long-lived. In fact, identification was only undertaken for one of the charcoal samples (BM-779; carbonized oak-galls). In addition, full information is unavailable about the particle-size range of the material (in particular whether it was finely divided, and therefore especially liable to postdepositional movement) or about the volume of soil from which it was extracted. Thus it is not possible to judge the security of context of these samples. In this respect, the Grimes Graves database is similar to many sets of existing ${ }^{14} \mathrm{C}$ data, most of which contain large numbers of measurements made on unidentified charcoals, about which the same provisos apply. If anything, the Grimes Graves material is atypical in the low number of charcoal samples included, because of the widespread availability of antler from the site.

The antler samples are not subject to such caveats of long life; they represent a single year's growth, and curation, storage or reuse over periods measurable by ${ }^{14} \mathrm{C}$ seem unlikely. Here, however, a different set of problems arises. Arguably, all the antler found in the shafts relates in some way to human activity, and was deliberately brought to the site to be used. However, on closer examination of their contexts, many of the samples included in the database proved to come from the infill of the shafts. This must severely limit their usefulness as a means of dating the construction and use of these features; they will have reached their final contexts either accidentally, falling from the surfaces above, or deliberately, as a means of disposal of discarded, possibly broken, objects. As such, they could either pre- or postdate the construction of the shaft in which they were found. They do not even necessarily date the period of infilling; they relate instead to some undetermined and undeterminable point prior to this when they were disposed of. This situation points up a possible source of misunderstanding between archaeologist and ${ }^{14} \mathrm{C}$ scientist. Most submission forms for ${ }^{14} \mathrm{C}$ dating contain a question relating to the contextual security of any proposed sample. These antler samples are archaeologically secure-they come from fixed and known contexts, from which they have not moved since antiquity-but they are by no means chronologically secure. For this study, such samples are therefore regarded as flawed and have been removed from any further analysis. In this, Grimes Graves is again typical of many, if not most, archaeological sites dated by ${ }^{14} \mathrm{C}$ over the past $40 \mathrm{yr}$; detailed examination of the results from any such site will show that many analyses included do not, and cannot, truly reflect the age of the events they were intended to date.

Even when these figures are deleted, a large number of relevant analyses remain. That there are so many good dating samples is due largely to the nature of the site. It appears that the chambers at the bottoms of the deep shafts were worked sequentially. To avoid unnecessary effort, chalk spoil and 
some of the discarded tools were not taken to the surface for disposal, but were instead thrown into areas that had already been worked out. In addition, numbers of antler picks were discarded on working surfaces, and some were actually used as pit props to reinforce the chamber ceilings. All dates on such material (identifiable in Table 1 by the presence of a gallery number in the description) are regarded here as relating to the working period of the relevant shaft.

With the original data reduced to a considerably smaller subset by these considerations, an attempt was made to apply the "interval" function of OxCal, the Bayesian based program of Bronk Ramsey (1995) to determine the duration of usage of each of the two shafts (Pit 15 and Greenwell's Pit), for which a sizable number of analyses still remained. This indicated a span of use of between 230 and $360 \mathrm{yr}$ for Pit 15, and between 80 and $240 \mathrm{yr}$ for Greenwells Shaft, at the $68 \%$ probability level (see Figs. 1A and 1B). While not impossible, these dates seem highly unlikely, both in view of the archaeological interpretation, and in purely practical terms. Felder (1981) and Longworth and Varndell (1996) calculated, using data from the British Museum reexcavation of the shaft plus some other evidence, that it would take on the order of 650 man-days to dig Greenwell's Pit. The time period this would imply obviously depends on the size of the workforce. Felder (1981) suggests on the grounds of space that between 14 and 20 people may have dug the main body of the pit, with only 4 to 6 able to work in the restricted space at the base of the shaft, although others could have been involved in the removal of spoil. Working out along the galleries, space would be further restricted, although it would be possible to use an assistant to clear spoil removed by the actual miner. On this basis, and with considerable margins of error, the time taken to complete the excavation and extraction of flint from Greenwell's Pit could have been on the order of 93 days. Even if this
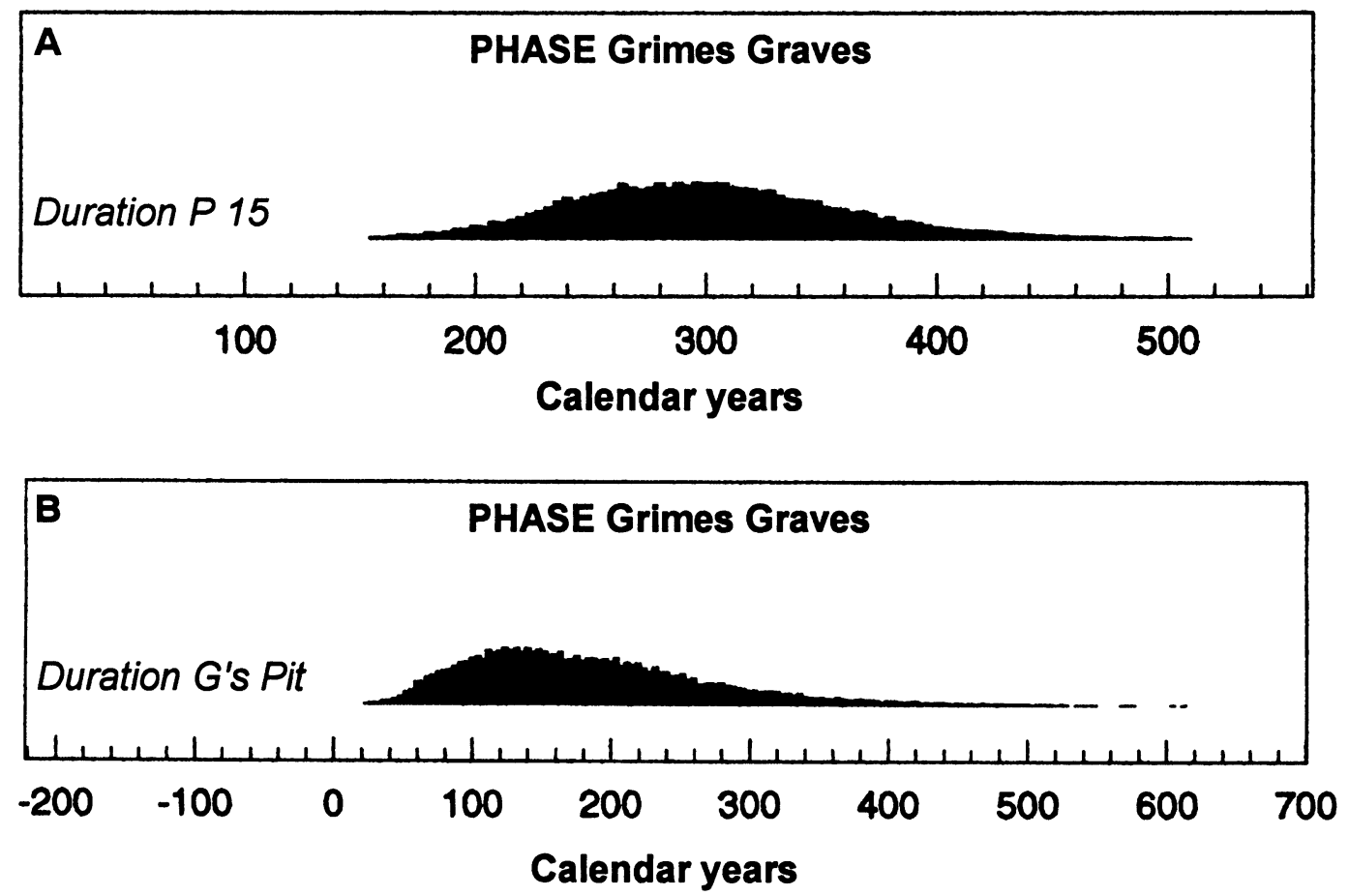

Fig. 1. Usage duration of Pit 15 (A) and Greenwell's Pit (B) as estimated by OxCal (Bronk Ramsey 1995) 
archaeological interpretation is totally incorrect, there are still practical limitations; it is difficult to envisage a shaft of this nature, sunk into the relatively soft chalk bedrock, remaining open and workable for anything like the period indicated by the ${ }^{14} \mathrm{C}$ dates.

Under these circumstances, and particularly given that some of the measurements involved were made $>30 \mathrm{yr}$ ago, it seems reasonable to look for possible flaws in the analyses themselves. It is now generally acknowledged that, before the widespread introduction of full quality control measures, laboratories tended to overestimate both the accuracy and precision of ${ }^{14} \mathrm{C}$ results-an inference supported by several intercomparison studies (e.g., Aitchison et al. 1990). Further evidence of the difficulty of maintaining a reliable ${ }^{14} \mathrm{C}$ measurement system is provided by the decision by the British Museum to withdraw and reissue all analyses issued by the laboratory between 1980 and 1984 (Bowman, Ambers and Leese 1990). While this is perhaps the most spectacular example of a laboratory recognizing and attempting to correct for a flaw in its methods, it is by no means unique. The reaction of the ${ }^{14} \mathrm{C}$ community to these failings has been to institute systems of quality control, designed to alert laboratory personnel to systemic problems, and quality assurance, designed to demonstrate high laboratory standards and consistently correct results to those outside the laboratory (Mook 1990; Long 1990). There remains, however, the difficulty of assessing the quality of results generated before the institution of these measures. It is not sufficient to rely solely on when samples were analyzed, and discard only older results; the British Museum example demonstrates clearly that a system functioning perfectly well in 1979, when an intercomparison exercise was carried out with other British laboratories (Otlet et al. 1980), could be experiencing major distortions only one year later. The only possible way of checking the validity of extant ${ }^{14} \mathrm{C}$ dates is to look at some form of quality control data for the relevant laboratory and time period. Unfortunately, adequate figures for this purpose are very rare in all cases and do not exist for these results. It was therefore felt that the only reliable way to date this site would be to repeat a selected subset of the measurements.

\section{QUALITY ASSURANCE AT THE BRITISH MUSEUM}

Before attempting any redating of Grimes Graves material, it is obviously necessary to demonstrate that any results now generated are correct. This requires that a set of quality control and assurance measures be in place. While such techniques include a raft of measures, such as adequate documentation and record keeping, the most vital factor is the maintenance of strict checks on standards. When the British Museum Laboratory recommenced counting after the closure period during 1980 1984 , a series of such quality control measures were instituted. The main points of this program are the inclusion in the counting chain of at least two backgrounds, two moderns and one sample of known age, replaced at staggered intervals of $c a .6-12$ months. Background and modern count rates are constantly monitored and subject to statistical analysis, and any indication of divergence of the pairs, or from expected statistical patterns, are immediately investigated, if necessary by stopping the counter. In addition, a sealed hot standard is used to monitor counter efficiency. The known-age samples are generated from cellulose extracted from bog oak, kindly supplied by M. L. Baillie and $\mathrm{J}$. Pilcher of Queens University, Belfast. This wood is dated dendrochronologically against the Belfast master, and the bidecadal sections used are chronologically identical to those used in the production of the Belfast high-precision calibration data. While the background and modern standards provide checks against one another, these known-age samples provide periodic checks of the whole dating system from raw materials to benzene. ${ }^{14} \mathrm{C}$ results for these samples are produced at weekly intervals using the normal laboratory analysis program and the figures produced subject to statistical analysis. In addition, each time a ${ }^{14} \mathrm{C}$ result is produced for an unknown sample, a known-age result 
is generated for the same time period. Using such material as a standard not only demonstrates the reliability and consistency of the system, but also ties results issued by the BM laboratory directly to the calibration curve used. Table 2 gives the results for the first four weeks of counting of some of these known-age samples, together with the Belfast figure for wood of the same age (results have been included here only where there are a number of figures for material of the same age; several single analyses also exist). These figures serve to justify the accuracy and precision of the British Museum ${ }^{14} \mathrm{C}$ laboratory.

TABLE 2. Results for Known-Age Wood Samples

\begin{tabular}{lccc}
\hline BM- no. & $\begin{array}{c}\text { Reported result } \\
(\mathrm{BP})\end{array}$ & $\begin{array}{c}\text { Unrounded result } \\
(\mathrm{BP})\end{array}$ & $\begin{array}{c}\text { Belfast result* } \\
(\mathrm{BP})\end{array}$ \\
\hline BM-2746 & $1060 \pm 50$ & $1059 \pm 52$ & $1020 \pm 17$ \\
BM-2745 & $980 \pm 45$ & $981 \pm 44$ & $1020 \pm 17$ \\
BM-2564 & $1060 \pm 50$ & $1060 \pm 45$ & $1020 \pm 17$ \\
BM-2563 & $1020 \pm 50$ & $1017 \pm 44$ & $1020 \pm 17$ \\
BM-2432 & $1030 \pm 50$ & $1029 \pm 47$ & $1020 \pm 17$ \\
BM-2432L & $1000 \pm 40$ & $999 \pm 37$ & $1020 \pm 17$ \\
Mean of $B M$ results & & 1024 & \\
BM-2768 & $4300 \pm 60$ & $4303 \pm 63$ & $4364 \pm 14$ \\
BM-2580 & $4340 \pm 50$ & $4337 \pm 43$ & $4364 \pm 14$ \\
BM-2561 & $4360 \pm 50$ & $4362 \pm 45$ & $4364 \pm 14$ \\
BM-2560 & $4360 \pm 50$ & $4364 \pm 47$ & $4364 \pm 14$ \\
BM-2617 & $4310 \pm 60$ & $4309 \pm 56$ & $4364 \pm 14$ \\
BM-2616 & $4370 \pm 50$ & $4368 \pm 48$ & $4364 \pm 14$ \\
Mean of $B M$ results & & 4341 & \\
BM-2747 & $2870 \pm 50$ & $2869 \pm 47$ & $2886 \pm 12$ \\
BM-2562 & $2920 \pm 50$ & $2920 \pm 53$ & $2886 \pm 12$ \\
BM-2494 & $2880 \pm 40$ & $2879 \pm 39$ & $2886 \pm 12$ \\
BM-2811 & $2870 \pm 45$ & $2871 \pm 46$ & $2886 \pm 12$ \\
BM-2493 & $2840 \pm 40$ & $2835 \pm 37$ & $2886 \pm 12$ \\
Mean of BM results & & 2875 & \\
\hline
\end{tabular}

*For wood of the same age; Pearson et al. (1986).

\section{NEW MEASUREMENTS}

A number of new ${ }^{14} \mathrm{C}$ analyses have been carried out on antlers from firm gallery contexts. The results to date are listed in Table 3 (quoted in the form recommended by Stuiver and Polach (1977), and corrected for isotopic variation as shown). This work is at an early stage, and more results will undoubtedly be necessary. However, while the new figures do not indicate a significant change in the date of mining at the site, they already suggest a much tighter grouping, more in accord with the archaeological interpretation, than the previous results (in fact, the results are statistically indistinguishable within individual shafts).

Calibrated age ranges were generated from the curve listed, using the program OxCal (Bronk Ramsey 1995) and are quoted in the form recommended by Mook (1986). The choice of calibration curves used here could perhaps be argued. While the results relate to antler and are therefore representative of the atmospheric ${ }^{14} \mathrm{C}$ level of a single year, for calibration I have used a curve based on bidecadal measurements. This is less than ideal, but is felt to be the best compromise possible, given the range of internationally ratified calibration curves currently available. 
TABLE 3. New Radiocarbon Results for the Deep Mines at Grimes Graves

\begin{tabular}{|c|c|c|c|c|c|c|c|c|}
\hline \multirow{2}{*}{$\begin{array}{l}\text { BM- } \\
\text { no. }\end{array}$} & \multirow[b]{2}{*}{ Material } & \multirow[b]{2}{*}{ Pit no. } & \multirow{2}{*}{$\begin{array}{l}\delta^{13} \mathrm{C} \\
(\% 0)\end{array}$} & \multirow[b]{2}{*}{ Context } & \multirow{2}{*}{$\begin{array}{l}\text { Find } \\
\text { no. }\end{array}$} & \multirow{2}{*}{$\begin{array}{l}{ }^{14} \mathrm{C} \text { age } \\
\text { (yr BP) }\end{array}$} & \multicolumn{2}{|c|}{$\begin{array}{l}\text { Possible calibrated age range(s) } \\
\text { (calendar yr BC) }\end{array}$} \\
\hline & & & & & & & $68 \%$ probability & $95 \%$ probability \\
\hline $\begin{array}{l}\text { 1. Pit } \\
3007\end{array}$ & $\begin{array}{l}15 \\
\text { Antler }\end{array}$ & $15 \mathrm{C} 2$ & -23.8 & Gallery & 60 & $4060 \pm 90^{*}$ & $\begin{array}{l}2860 \text { to } 2820 \text { or } \\
2620 \text { to } 2460\end{array}$ & 2900 to 2300 \\
\hline $\begin{array}{l}3090 \\
3087\end{array}$ & $\begin{array}{l}\text { Antler } \\
\text { Antler }\end{array}$ & $\begin{array}{l}15 \mathrm{~B} 3 \\
15 \mathrm{~B} 1\end{array}$ & $\begin{array}{l}-20.4 \\
-23.4\end{array}$ & $\begin{array}{l}\text { Gallery } \\
\text { Gallery }\end{array}$ & $\begin{array}{l}30 \\
103\end{array}$ & $\begin{array}{l}4010 \pm 70^{*} \\
4010 \pm 40^{*}\end{array}$ & $\begin{array}{l}2620 \text { to } 2450 \\
2590 \text { to } 2470\end{array}$ & $\begin{array}{l}2900 \text { to } 2300 \\
2860 \text { to } 2820 \text { or } \\
2620 \text { to } 2460\end{array}$ \\
\hline $\begin{array}{l}\text { 2. } G r \\
3009\end{array}$ & $\begin{array}{l}\text { eenwell's I } \\
\text { Antler }\end{array}$ & $\begin{array}{l}\text { it } \\
\text { Greenwell IV }\end{array}$ & -21.4 & Gallery & 578 & $4060 \pm 90^{*}$ & $\begin{array}{l}2870 \text { to } 2810 \text { or } \\
2770 \text { to } 2720 \text { or }\end{array}$ & 2900 to 2350 \\
\hline 3010 & Antler & Greenv & -22.7 & Gallery & 705 & $3960 \pm 45^{*}$ & $\begin{array}{l}2700 \text { to } 2490 \\
2580 \text { to } 2530 \text { or } \\
2510 \text { to } 2450\end{array}$ & 2610 to 2330 \\
\hline 3089 & Antler & Greenwell IIb & -21.7 & Gallery & 900 & $3960 \pm 60^{*}$ & $\begin{array}{l}2580 \text { to } 2490 \text { or } \\
2430 \text { to } 2360\end{array}$ & $\begin{array}{l}2900 \text { to } 2800 \text { or } \\
2700 \text { to } 2250\end{array}$ \\
\hline 3088 & Antler & Greenwell A & -22.3 & Gallery & 923 & $3980 \pm 60^{*}$ & $\begin{array}{l}2610 \text { to } 2450 \text { or } \\
2420 \text { to } 2400\end{array}$ & $\begin{array}{l}2900 \text { to } 2800 \text { or } \\
2700 \text { to } 2300\end{array}$ \\
\hline
\end{tabular}

*Pearson et al. (1986)

\section{CONCLUSION}

The Grimes Graves ${ }^{14} \mathrm{C}$ database discussed above is probably typical of many such sets of archaeologically derived ${ }^{14} \mathrm{C}$ results. While it initially appears to be both extensive and comprehensive, detailed examination of its contents rapidly demonstrates that many of the figures included do not, and cannot, relate to any event of archaeological interest in anything other than the most tangential way. Any archaeological interpretation that includes such figures will therefore be invalid. Similarly, the whole of this database was generated prior to the introduction of properly constituted and demonstrable quality control measures. For this reason, although these results may well be correct, they cannot be independently verified, and hence must be treated with a degree of caution, if not suspicion. In this particular case it is possible to deduce from the archaeology and from sheer common sense that the time scale indicated by the existing database is impossible, and that at least some of the included analyses are incorrect. Other archaeological databases must be similarly flawed, but in few instances will this be so obvious. This study must serve to emphasize that, for any archaeological phenomenon apparently dated by ${ }^{14} \mathrm{C}$ in the past $40 \mathrm{yr}$, vigorous individual reassessment of the true chronological meaning of each of the measurements is an absolute necessity prior to any attempt to establish time scales. This is especially important now, with the increasing availability of powerful PC-based statistical tools, such as the OxCal program. While this is a huge step forward for archaeology, opening up a whole new field of interpretation, incautious use of such techniques can lead to false conclusions, backed by apparently cogent statistical arguments.

For many ${ }^{14} \mathrm{C}$ databases, from individual sites and from larger groupings of culture or period, such sifting will greatly reduce the number of measurements available. Selective redating of carefully selected materials, by laboratories with clearly demonstrable quality assurance and quality control programs in place, rnust be the best answer. 


\section{REFERENCES}

Aitchison, T. C., Scott, E. M., Harkness, D. D., Baxter, M. S. and Cook, G. T. 1990 Report on Stage 3 of the International Collaborative Program. In Scott, E. M., Long, A. and Kra, R. S., eds., Proceedings of the International Workshop on Intercomparison of ${ }^{14} \mathrm{C}$ Laboratories. Radiocarbon 32(3): 271-278.

Armstrong, A. L. 1934 Grimes Graves, Norfolk. Report on the excavation of Pit 12. Proceedings of the Prehistoric Society of East Anglia 7(1): 57-61.

Bowman, S. G. E., Ambers, J. C. and Leese, M. N. 1990 $\mathrm{Re}$-evaluation of British Museum ${ }^{14} \mathrm{C}$ dates issued between 1980 and 1984. Radiocarbon 32(1): 59-79.

Bronk Ramsey, C. 1995 Radiocarbon calibration and the analysis of stratigraphy: The OxCal program. In Cook, G. T., Harkness, D. D., Miller, B. F. and Scott, E. M., eds., Proceedings of the 15 th International ${ }^{14} \mathrm{C}$ Conference. Radiocarbon 37(2): 425-430.

Felder, P. J. 1981 Prehistoric flint mining at Ryckholt St Geertruid (Netherlands) and Grimes Graves (England). In Engelen, F. H. G., ed., Proceedings of the Third International Symposium on Flint, 24-27 May 1979, Maastricht. Nederlandse Geologische Vereniging: $146 \mathrm{p}$.

Long, A. 1990 A quality assurance protocol for radiocarbon dating laboratories. Radiocarbon 32(1): 109-112.

Longworth, I. and Varndell, G. 1996 The Excavations at Grimes Graves, Norfolk 1972-1976. Fascicule 5. Mining in the Deeper Mines. London, British Museum Press: $110 \mathrm{p}$.
Mercer, R. J. 1981 Grimes Graves, Norfolk: Excavations 1971-72. DOE Excavation Report 11. London, HMSO: $70 \mathrm{p}$.

Mook, W. G. 1986 Business meeting: Recommendations and resolutions adopted by the twelfth international radiocarbon conference. In Stuiver, $\mathrm{M}$. and $\mathrm{Kra}, \mathrm{R}$., eds., Proceedings of the 12 th International ${ }^{14} \mathrm{C}$ Conference. Radiocarbon 28(2A): 799.

1990 Special report from the Glasgow intercomparison workshop on quality control and assurance. $R a$ diocarbon 32(1): 107-108.

Otlet, R. I., Walker, A. J., Hewson, A. D. and Burleigh, R. $1980{ }^{14} \mathrm{C}$ interlaboratory comparison in the UK: Experimental design, preparation and preliminary results. In Stuiver, M. and Kra, R. S., eds., Proceedings of the 10th International ${ }^{14} \mathrm{C}$ Conference. Radiocarbon 22(3): 936-946.

Peake, A. E. 1919 Further excavations at Grimes Graves. Proceedings of the Prehistoric Society of East Anglia 3(1): 73-93.

Pearson, G. W., Pilcher, J. R., Baillie, M. G. L., Corbett, D. M. and Qua, F. 1986 High-precision ${ }^{14} \mathrm{C}$ measurements of Irish Oaks to show the natural variations from AD 1840 to 5210 BC. In Stuiver, M. and Kra, R., eds., Calibration Issue. Radiocarbon 28(2B): 911934.

Stuiver, M. and Polach, H. A. 1977 Discussion: Reporting of ${ }^{14} \mathrm{C}$ data. Radiocarbon 19(3): 355-363.

\section{APPENDIX: BRITISH MUSEUM DATE LISTS CITED}

III: Barker, H. and Mackey, J. 1961. British Museum natural radiocarbon measurements III. Radiocarbon 3: $39-45$.

IV: Barker, H. and Mackey, J. 1963 British Museum natural radiocarbon measurements IV. Radiocarbon 5: $104-108$.

VI: Barker, H., Burleigh, R. and Meeks, N. 1969 British Museum natural radiocarbon measurements VI. Radiocarbon 11(2): 278-294.

VIII: Burleigh, R., Hewson, A. and Meeks, N. 1976 British Museum natural radiocarbon measurements VIII. Radiocarbon 18(1): $16-42$.

X: $\quad$ Burleigh, R., Hewson, A., Meeks, N., Sieveking, G. and Longworth, I. 1979 British Museum natural radiocarbon measurements X. Radiocarbon 21(1): 41-47.

XX: Ambers, J, Matthews, K. and Bowman, S. 1987 British Museum natural radiocarbon measurements XX. Radiocarbon 29(1): 177-196. 